\title{
Analysis of Anti-Retaliation Provisions of the Dodd-Frank Act in Relation to Foreign Whistleblowers
}

\author{
Vicki M. Stewart \\ Texas A \& M University Commerce
}

Given the increasing globalization of corporations and the interest of Congress in increasing the incentives for whistleblowing as shown in the Dodd-Frank Wall Street Reform and Consumer Protection Act of 2010 (hereinafter Dodd-Frank Act or Act), the absence of significant anti-retaliation protection for foreign whistleblowers is of concern. The Supreme Court has ruled that it will not extend United States security laws to extraterritorial jurisdictions in Morrison v. National Australia Bank thereby limiting the ability of foreign whistleblowers to participate in the anti-retaliation provisions of the Dodd-Frank Act. The paper will first review the whistleblowing and anti-retaliation provisions of the Act before addressing whether the lack of these protections for foreign whistleblowers could undermine the effectiveness of the Act in relation to possible infractions by foreign corporation registrants with the Securities and Exchange Commission (SEC). The paper cites data regarding the number of foreign whistleblower reports, foreign corporation SEC registrants, and enforcement proceedings of the Public Company Accounting Oversight Board (PCAOB) to provide a basis for the conclusions reached.

\section{INTRODUCTION}

In the aftermath of the 2008 financial crisis following the implosion of the mortgage-backed securities market and the well-publicized Bernie Madoff scandal, Congress passed the Dodd-Frank Wall Street Consumer Reform and Consumer Protection Act of 2010. Included in the Act were significant provisions to encourage whistleblowers to come forward with information regarding potential securities' law violations. Whistleblowing regulations existed prior to the passage of the Dodd-Frank Act as well as anti-retaliation provisions to protect whistleblowers, but they were not as effective as the legislature felt was necessary. Thus, the whistleblower regulations in general as well as anti-retaliation provisions were expanded and strengthened. Meanwhile, the Supreme Court reviewed the previous court decisions made regarding extraterritorial application of US securities laws in the landmark case, Morrison v. National Australia Bank. This decision effectively dismissed security law cases of foreign origination from US courts due to the absence of precise extraterritorial application written into the legislation. The DoddFrank Act language did not change the application of the securities law to include foreign cases. Given the globalization of corporations and registration of foreign corporations with the SEC, the question arises as to whether the intention of the legislature to encourage whistleblowing diminishes due to the inability of foreign whistleblowers to benefit from the anti-retaliation provisions of Dodd-Frank. This paper will examine these issues in the context of whistleblower reports per Dodd-Frank in relation to the number of foreign SEC registrants and the current enforcement efforts of the PCAOB. 


\section{WHISTLEBLOWER ANTI-RETALIATION PROVISIONS UNDER SOX}

Modern whistleblowing and related anti-retaliation provisions related to the securities laws began with the Sarbanes-Oxley Act of 2002 (SOX) and review of the provisions included in SOX is important to an understanding of the expanded provisions under Dodd-Frank. Like the situation prior to the passage of the Dodd-Frank Act, Congress reacted to the widespread corporate financial scandals, especially Enron, by passing SOX. Congress heard testimony given by of Sherron Watkins, an Enron vice-president, who anonymously reported the complex accounting schemes used to inflate Enron's values to both the CFO and Enron board. In retaliation to her disclosure, Enron sought to fire Watkins. However, legal counsel advised against her termination and Enron subsequently relegated Watkins to performing only menial work in her executive office suite. Because of this testimony, Congress included in this legislation directed at improving financial reporting and disclosure significant whistleblowing anti-retaliation provisions (Gilpin, 2017).

"SOX prohibits publicly traded companies including subsidiaries or affiliates whose financial statements are included in consolidated financial statements of such companies, and nationally-rated statistical rating organizations from discharging, demoting, suspending, threatening, harassing or in any other manner discriminating against any employee because such employee-provided information, caused such information to be provided, otherwise assisted in an investigation, testified, or participated in a proceeding regarding any conduct that the employee reasonably believes is a violation of SOX, any SEC rule or regulation or any federal statute relating to fraud against shareholders, when the information is provided to a federal law enforcement or regulatory agency, any Member or committee of Congress, or a person with supervisory authority over the employee or investigative authority for the employer" (Shimabukuro, Whitaker, \& Roberts, 2013, p. 42). SOX created whistleblower anti-retaliation provisions that provided both courts and administrative agencies the ability to use both monetary and non-monetary means to make the whistleblower whole. Most of the remedies available to whistleblowers under SOX were identical to those provided for discrimination cases, such as reinstatement of the job if fired, payment of back pay with interest, and reimbursement of various litigation costs (Sipe, Metrejean \& Pearson, 2014). SOX requires that any employee who alleges discrimination or discharge in violation of the SOX whistleblower provisions to file a complaint with the Secretary of Labor within 180 days after the violation occurs or within 180 days from the date the employee became aware of the violation. The employee has the right to file a claim in district court if the Secretary of Labor fails to respond to the claim within 180 days of the filing (Shimabukuro et al., 2013). The Department of Labor prescribes filing the claim of retaliation through the Occupational Safety and Health Administration (OSHA), which investigates the claim and issues an administrative law order, subject to a hearing, with appeal available through an Administrative Review Board (Sipe et al. 2014).

Some weaknesses identified in the SOX anti-retaliation provisions include the provision that only employees of publicly traded corporations are covered by the provisions thus excluding quasi-insiders doing work for the corporations who may have valuable inside information (Sipe et al. 2014). Others include the requirement to exhaust administrative procedure requirements through OSHA prior to seeking relief in district court and the relatively short statute of limitations for filing a claim (Gilpin, 2017).

These weaknesses were at least partially responsible for the rather anemic SOX whistleblower protection through 2010 of only 17 out of 1,000 whistleblower cases reported to OSHA deemed as having merit and allowed to proceed. OSHA dismissed most cases, 655, as having no merit; 126 cases were withdrawn and 138 settled prior to a ruling (Sipe et al. 2014). Due to these perceived inadequacies, Congress acted later to strengthen anti-retaliatory measures both in the original provisions in SOX and in additional measures contained in the Dodd-Frank Act.

\section{WHISTLEBLOWER ANTI-RETALIATION PROVISIONS UNDER DODD-FRANK}

Similar, but perhaps even more dire, circumstances than Enron provided the backdrop for the DoddFrank Act of 2010. As Lehman Brothers went into bankruptcy and liquidity in the commercial paper 
market quickly dried up, the financial crisis of 2008 drove Congress once again into drafting legislation with more stringent financial market regulation (Gilpin, 2017). Congress heard and reacted this time to the testimony of financial-analyst-turned investigator, Harry Markopolos, concerning his inability to convince the SEC for almost a decade to investigate Bernard Madoff's multi-billion-dollar Ponzi scheme (Carozza, 2009). Markopolos specifically cited the need for stronger whistleblower provisions with mandatory awards (Uliassi, 2011).

The Dodd-Frank Act amended the Securities and Exchange Act of 1934, by adding a new Section 21(f), entitled, "Securities Whistleblower Incentives and Protections," (Securities and Exchange Commission, 2011). Section 922 of the Act enhanced the SEC's whistleblower bounty program requiring an award of 10 to 30 percent of the sanctions imposed exceeding $\$ 1,000,000$ (Uliassi, 2011). Prior to this, the SEC bounty program under the Exchange Act of 1934 only allowed awards up to 10 percent of sanctions collected for insider trading and those rewards were not guaranteed, resulting in only five awards in 20 years totaling \$159,357 (Miralem, 2011). In addition, Section 924 directed the SEC to create a separate office, termed the Office of the Whistleblower (OWB), within the SEC to administer and enforce the whistleblower program including the duties of defining terms, establishing procedures and criteria for making awards as well as implementing the anti-retaliation provisions of Dodd-Frank (SEC, 2011).

One of the improvements instituted by Dodd-Frank was the extension of anti-retaliation provisions to parties other than employees of publicly traded companies. Now, the Act protects employees of private companies, agents, and contractors who work for public companies as well as employees of private subsidiaries whose financial results are included in the consolidated returns of public companies (Sipe et al. 2014).

The statute of limitations for filing claims expanded from the 180 days offered under SOX to six years after the date the retaliation occurs or within three years from the date when the employee knew of or should have known of the facts but no more than 10 years after the violation. In addition, the whistleblower has the right to proceed directly to district court rather than file a claim through an administrative agency (Sipe et al. 2014). The remedies for employees subjected to retaliation also increased to two times the back pay including interest in addition to reasonable attorney's fees and litigation costs (Miralem, 2011).

Provisions against mandatory arbitration agreements and for anonymous reporting of violations directly to the SEC instead of having to report first internally are some added improvements of DoddFrank to encourage reporting of violations without fear of retaliation (Sipe et al. 2014). However, some believe the bounty provisions and lack of required internal reporting have undermined the internal compliance programs required by SOX. However, research shows that without whistleblowers there would be less compliance with securities laws (Miralem, 2011).

The latest OWB annual report to Congress for FY 2016 stated that since the program's establishment in 2011, the agency has awarded \$111 million to 34 whistleblowers. Given that the main responsibility of the office is to provide a monetary incentive for reporting violations, much of the work of the OWB relates to processing claims for whistleblower awards. However, the OWB processed its first stand-alone whistleblower retaliation case in 2016 indicating the high priority placed by the OWB on ensuring a safe environment for whistleblowers (SEC, 2016).

\section{WHISTLEBLOWING AND COMPLIANCE WITH LAWS}

Federal law contains at least forty laws with protection for whistleblowers who report some type of misconduct by their employers or who engage in protected activities, such as participating in an investigation or filing a claim (Shimabukuro, et al. 2013). This shows the importance that Congress has placed not only whistleblowing but also on whistleblower protection to advance compliance with these laws. The earliest and one of the most successful, The False Claims Act of 1863, provides for whistleblower protection and in 2010 alone allowed the Department of Justice to recover $\$ 3$ billion and award whistleblowers \$385 million (Miralem, 2011). Although much newer, the SEC's program under

Journal of Accounting and Finance Vol. 19(3) 2019135 
Dodd-Frank is no exception with $\$ 1$ billion recovered to date, by investors and the US Treasury, directly tied to original information (Kohn, 2017).

With the interest of Congress in compliance and the success of the programs evident, Dodd-Frank's whistleblowing provisions not only encourage the reporting of tips to the SEC but also encourage selfreporting of wrongdoing by companies. SEC Chairwoman, Mary Jo White, spoke to this during 2015 stating that companies now have an incentive to self-report their own noncompliance or someone else may do it for them (Kohn, 2017). Since employees are in the best position to uncover and report violations, companies have an incentive to create more effective internal control compliance or face the harsher and more frequent penalties associated with whistleblowing (Miralem, 2011).

Data shows that economic crime is a real problem for organizations globally. PricewaterhouseCoopers (PWC) 2016 survey of over 6,000 companies showed that 36\%, more than 1 in 3 , experienced some type of economic crime. Losses can be stiff as much as $\$ 100$ million for $1 \%$ of the respondents but still significant at between $\$ 100,000$ and $\$ 1$ million for $22 \%$ and above $\$ 1$ million for $14 \%$. More than half the perpetrators are middle and senior managers, but junior managers also contributed to internal fraud that makes up $46 \%$ of the fraud experienced, pointing to a weakness in internal controls. The most likely characteristics of the internal fraudster are a male college graduate 3140 years old with 3 to 5 years of service (PWC, 2016).

Given the prevalence of economic crime, companies have tried to combat it with internal control programs. PWC's survey found that $82 \%$ of all companies surveyed had formal business ethics and compliance programs. However, these internal control programs proved $7 \%$ less effective in detecting and preventing economic crime than when last surveyed in 2014. Nearly three-quarters of the companies (76\%) rely on internal audit functions to assess the effectiveness of their compliance programs. Unfortunately, while $86 \%$ had formal codes of conduct, only $64 \%$ reported regularly providing training and supporting advice and communication. The survey indicates that there is perception gap between what the CEOs and boards communicate and what the employees perceive. This is particularly true for middle managers who are the most likely to commit fraud and the group who feels most that values are not clearly communicated nor are incentive programs fair (PWC, 2016).

Congress considered the effect of disincentives to the reporting of infractions internally when drafting Dodd-Frank. Supporters of requiring internal reporting first cited the benefits of allowing companies to act earlier, the desire not to undermine internal control programs, to save scarce SEC resources, and to maintain better working relationships between the SEC and companies. Opponents cited among the problems associated with the requirement to report internally first the lack of reporting caused by fear of retaliation by whistleblowers. The SEC decided that it was best not to require mandatory internal reporting because internal compliance programs, while important, are not substitutes for rigorous law enforcement (Miralem, 2011).

\section{WHISTLEBLOWING AND RETALIATION}

For the first time in 2016, the Ethics \& Compliance Initiative (ECI) conducted a Global Business Ethics Survey (GBES) of 13,046 participants located in 13 countries: Brazil, China, France, Germany, India, Italy, Japan, Mexico, Russia, South Korea, Spain, the United Kingdom, and the United States. The four key metrics included positive responses from survey participants to pressure to compromise organizational standards (22\%), observed misconduct (33\%), reporting of misconduct when observed $(59 \%)$, and retaliation against reporters (36\%). As more companies expand globally, businesses become more complicated and challenges to workplace integrity increase making this type of survey data important (ECI, 2016).

The survey showed that employees of multinational companies are $7 \%$ more likely to feel pressure to compromise standards and to observe misconduct than employees who operate in a single country. Companies identified as suppliers experienced more pressure $(8 \%)$, more misconduct $(11 \%)$ and more retaliation (12\%) than non-supplier companies did. The presence of pressure to compromise organizational standards sets the stage for observed misconduct as the survey showed that where there 
was pressure present nearly $73 \%$ of respondents also observed misconduct. Brazil, India, and Russia experience significantly more pressure and misconduct than their counterparts did, perhaps due to increased levels of organizational change. Interestingly, the common types of misconduct around the world varied little with employees in almost every country citing lying to employees, customers and vendors or the public as well as abusive behavior more frequently than any other forms of misconduct asked about (ECI, 2016).

While fear of retaliation was cited as the principle reason $(56 \%)$ why respondents did not report wrongdoing, the survey showed that the areas where reporting was the highest were also areas where retaliation against reporters was the highest. While the majority (59\%) of employees report misconduct, one-third of the reporters suffer retaliation for doing so. Most employees, four out of five, who suffered from retaliation, did so within the first three weeks of reporting and $90 \%$ reported retaliation occurred within 6 months of reporting (ECI, 2016). A survey of 75 attendees at an Institute of Management conference reported similar findings of $60 \%$ reporting misconduct and for the $40 \%$ who remained silent fear of retaliation, including job loss, was the most common reason cited for not reporting. Both reporters and those who remained silent were comprised of similar professionals, most having a CMA (Certified Management Account) and or CPA (Certified Public Accountant) certification and master's degrees (Fredin, 2012).

\section{EFFECTIVENESS OF DODD-FRANK ANTI-RETALIATION PROVISIONS}

The data shows that whistleblowing is effective in both encouraging greater compliance by companies and pursuing enforcement of the securities laws, but the fear of retaliation is one that clearly deters many would-be whistleblowers from reporting. This fact was not lost on Congress because both the Sarbanes-Oxley Act and Dodd-Frank included anti-retaliation provisions. Jurisprudence on whistleblower statutes also stands on the principle that employee protection from retaliation is essential in order to enforce societies civil and criminal laws (Miralem, 2011). The effectiveness of the more expanded DoddFrank anti-retaliation provisions seems clear, as the SEC prosecuted the first stand-alone case in 2016. This case involved a casino-gaming company, Information Game Technology (IGT), who fired an employee with several years of good performance reviews for reporting to both the company and the SEC problems with the IGT financial statements This OWB states that the strong enforcement of the antiretaliation protections is a critical component of the whistleblower program (OWB, 2016).

As previously stated, Congress seriously considered the effects of the bounty and anti-retaliation provisions on internal reporting. The final rules of Dodd-Frank incentivize the reporting of wrongdoing internally by allowing the same award if an employee reports to the internal compliance program and then the company self-reports, increasing awards for those whistleblowers who have first reported internally, and finally allowing a 120-day look-back period for employees to report internally and still report to the SEC (Miralem, 2011). However, the question of whether the protections offered by Dodd-Frank extend to employees if they only report internally without ever going to the SEC has been a source of confusion. The question has arisen regarding whether an individual who only reports internally is a whistleblower according to the definition in 21(f) given by Congress. The definition seems to exclude individuals who only report internally because it defines a whistleblower as an individual or two or more individuals who act jointly to provide information relating to a violation of securities laws to the Commission in a manner established by SEC rule or regulation (Sipe et al. 2014). On June 27, 2017, the Supreme Court agreed to hear the case of Somers v. Digital Realty Trust Inc. to decide who is a whistleblower and thereby included in the anti-retaliation and monetary awards under Dodd-Frank. The outcome of the case will have a significant effect on whether companies will face more external reporting by employees seeking retaliation protection (Dechert, 2017).

One group not participating in the anti-retaliation provisions is foreign whistleblowers. On July 24, 2010, the Supreme Court made a landmark ruling in Morrison v. National Australia Bank negating the extraterritorial reach of US Securities laws. Prior to Morrison, district courts had established various tests to extend jurisdiction to foreign cases in certain circumstances. The Supreme Court turned these on their 
head and instead held with the "longstanding principle of American law that legislation of Congress, unless a contrary intent appears, is meant to apply only within the territorial jurisdiction of the United States" (as cited in Elgadeh, 2011, p.582).

Around the same time that the Supreme Court made its ruling, Congress was drafting Dodd-Frank in the aftermath of the financial crisis. Until the passage of Dodd-Frank, after Morrison, neither the 1933 nor the 1934 Securities Acts had any mention of extraterritorial application and as the Supreme Court stated in Morrison, "when a statute gives no clear indication of an extraterritorial application, it has none" (as cited in Elgadeh, 2011, p. 585). The Dodd-Frank bill addressed a host of financial regulations but specifically included two sections, 929(p) and 929(y), intended to expand the securities acts extraterritorially. However, these sections while addressing the jurisdiction of the securities laws did not change their application. The Supreme Court has specifically addressed in Morrison that the courts had subject matter jurisdiction, but that Morrison failed not on jurisdiction but on merits. Thus, Dodd-Frank failed to extend the securities laws extraterritorially (Elgadeh, 2011).

The Second District Court on August 14, 2014 addressed the extraterritoriality of the anti-retaliation provision of Dodd-Frank in Liu v. Siemens AG. Liu Ming-Lin, a Taiwanese citizen and resident, filed suit against his employer, a Chinese subsidiary of German Siemens AG, claiming his termination resulted from reporting internally payments made in violation of the Foreign Corrupt Practices Act. The Court dismissed the case based on the Supreme Court's ruling in Morrison. In its ruling, the District Court dismissed the argument by Liu that the SEC regulations extending the bounty provisions to include foreign nationals provided a basis to extend the anti-retaliation provisions extraterritorially. The question of whether anti-retaliation measures are available when reporting only internally was not addressed. The important aspect of this case is that the Courts will continue to adhere to the Morrison precedence and presumption against the extraterritoriality of the anti-retaliation provisions of Dodd-Frank in all but the most clearly defined circumstances (Christian, Rosenfeld, Lakatos, Hanchet \& Bisanz, 2014).

\section{OFFICE OF WHISTLEBLOWING AND SEC FOREIGN REGISTRANT STATISTICS}

The Office of the Whistleblower (OWB) makes an annual report to Congress in accordance with section 924(d) each year in which they provide statistics on the activities of the office including the number of whistleblowing complaints received and the response of the office to the complaints (OWB, 2016). The annual statistics show the number of complaints by location, when provided, of the person placing the complaint, with tips coming from 103 different countries since the program's beginning. The OWB statistics, 2011 - 2016, for tips received summarized by location, internationally or within the United States, or no designation provided, are as follows:

TABLE 1

OFFICE OF WHISTLEBLOWER TIPS BY LOCATION 2011-2016

\begin{tabular}{|l|r|r|r|r|r|r|}
\hline Location & $\mathbf{2 0 1 1}$ & $\mathbf{2 0 1 2}$ & $\mathbf{2 0 1 3}$ & $\mathbf{2 0 1 4}$ & $\mathbf{2 0 1 5}$ & $\mathbf{2 0 1 6}$ \\
\hline International & $32^{\mathbf{r}}$ & $32 \mathbf{r}^{\mathbf{2}}$ & $\mathbf{4 0 4}$ & $\mathbf{4 4 8}$ & $\mathbf{4 2 1}$ & $\mathbf{4 6 4}$ \\
\hline United States & 215 & 2,507 & 2,250 & 2,683 & 2,892 & 3,087 \\
\hline No designation & 87 & 170 & 779 & 760 & 822 & 902 \\
\hline Total & $\mathbf{3 3 4}$ & $\mathbf{3 , 0 0 1}$ & $\mathbf{3 , 4 3 3}$ & $\mathbf{3 , 8 9 1}$ & $\mathbf{4 , 1 3 5}$ & $\mathbf{4 , 4 5 3}$ \\
\hline Percentage-Intl & $9.6 \%$ & $10.8 \%$ & $11.8 \%$ & $11.5 \%$ & $10.2 \%$ & $10.4 \%$ \\
\hline Percentage-US & $64.4 \%$ & $83.5 \%$ & $65.5 \%$ & $69.0 \%$ & $69.9 \%$ & $69.3 \%$ \\
\hline Percentage-No Des. & $26.0 \%$ & $5.7 \%$ & $22.7 \%$ & $19.5 \%$ & $19.9 \%$ & $20.3 \%$ \\
\hline
\end{tabular}

The OWB also provides information on the recipients of the awards granted noting that to date eight of the 34 reward recipients in 26 covered actions were foreign nationals at the time they submitted their 
tips. Noticeably, a foreign national received the highest award to date of \$30 million in September 2014. Five of the award cases involved two or more individuals submitting information jointly to the Commission and one-quarter of the award recipients reported their information anonymously. Sixty-five percent of the award recipients to date have been insiders of the entity and eighty percent raised concerns internally or felt that the companies were aware of their concerns prior to reporting to the SEC (OWB, 2016).

TABLE 2

SEC NUMBER OF INTERNATIONAL REGISTRANTS 2011-2016

\begin{tabular}{|l|rrrrrr|}
\hline Location & 2011 & 2012 & 2013 & 2014 & 2015 \\
\hline International & $965^{\prime}$ & $946^{\prime}$ & $940^{\prime}$ & 912 & 923
\end{tabular}

The five countries with the largest number of foreign registrants in 2015 were Canada (292), Cayman Islands (119), Israel (87), Marshall Islands (45), and United Kingdom (39) representing 582 of the total 923 foreign registrants or $63 \%$. Based on the information on the number of whistleblower tips originating from foreign locations, where provided, the average percentage of foreign tips, 10.71, from $2011-2016$, is consistent with the 2015 percentage of foreign SEC registrants. However, the countries where the tips originated do not correspond directly with the locations of the foreign SEC registrants except in the cases of Canada and the United Kingdom with $24 \%$ and $22 \%$, respectively, of the tips, and $32 \%$ and $4 \%$, respectively, of current foreign SEC registrants. However, many tip reporters, averaging 19\%, do not designate their location (OWB, 2016).

The OWB tips statistics also provide information on the nature of the complaints and for 2016 showed the three most common categories of complaints were corporate disclosures and financials $(22 \%)$, offering fraud $(15 \%)$, and manipulation $(11 \%)$. These three types of securities violations have remained consistent over the last five years as the most common violations reported (OWB, 2016). Since financial statements and disclosures are involved in at least $22 \%$ of the tips provided, information on enforcement activities on the firms that are auditing these financial statements can help shed more light on the international situation.

\section{PCAOB ENFORCEMENT AND REGISTRATION STATISTICS}

The Public Company Accounting and Oversight Board was created by the Sarbanes-Oxley Act of 2002 to oversee the audits of public companies in order to protect investors and the public interest by promoting informative, accurate and independent audit reports. While the PCAOB is a private nonprofit, the SEC has oversight authority over the PCAOB, including the approval of the Board's rules, standards, and budget. The PCAOB has authority to investigate and discipline registered public accounting firms for noncompliance with SOX, the rules of the PCAOB and the Securities and Exchange Commission and other laws, rules and professional standards governing the audits of public companies, brokers, and dealers. The PCAOB can impose appropriate sanctions for violations. The PCAOB also maintains a tip and referral center, citing that tips provide important sources of information (PCAOB, 2017).

As required by SOX, the PCAOB keeps its investigations and disciplinary proceedings confidential and nonpublic. The Board does provide information on settled disciplinary actions after the SEC has lifted its stay. The information provided on the website shows the location of the country of the respondent and the following summarized information shows the international and domestic settled disciplinary actions from $2011-2016$ : 
TABLE 3

PCAOB SETTLED DISCIPLINARY ACTIONS 2011-2016

\begin{tabular}{|l|r|r|r|r|r|r|r|}
\hline Location & $\mathbf{2 0 1 0}$ & $\mathbf{2 0 1 1}$ & $\mathbf{2 0 1 2}$ & $\mathbf{2 0 1 3}$ & $\mathbf{2 0 1 4}$ & $\mathbf{2 0 1 5}$ & $\mathbf{2 0 1 6}$ \\
\hline International & $\mathbf{2}$ & $\mathbf{2}$ & 0 & $\mathbf{2}^{\mathbf{r}}$ & $\mathbf{2}^{\mathbf{r}}$ & 2 & 24 \\
\hline United States & 5 & 6 & 8 & 11 & 22 & 42 & 30 \\
\hline Totals & $\mathbf{7}$ & $\mathbf{8}$ & $\mathbf{8}$ & $\mathbf{1 3}$ & $\mathbf{2 4}$ & $\mathbf{4 4}$ & $\mathbf{5 4}$ \\
\hline International-\% & $28.6 \%$ & $25.0 \%$ & $0.0 \%$ & $15.4 \%$ & $8.3 \%$ & $4.5 \%$ & $44.4 \%$ \\
\hline United States-\% & $71.4 \%$ & $75.0 \%$ & $100.0 \%$ & $84.6 \%$ & $91.7 \%$ & $95.5 \%$ & $55.6 \%$ \\
\hline
\end{tabular}

Accounting firms are required to register with the PCAOB to prepare or issue an audit report for a public company or another issuer, or a broker-dealer or to play a certain role in those audits. Information from the PCAOB website shows the international and United States firms currently registered and those currently performing audit functions:

TABLE 4

PCAOB REGISTERED FIRMS CURRENTLY PERFORMING AUDITS

\begin{tabular}{|l|r|r|}
\hline Locations & Registered & \multicolumn{1}{c|}{ Audits } \\
\hline International & 897 & 287 \\
\hline United States & 1,034 & 356 \\
\hline Total & 1,931 & 643 \\
\hline International-\% & $46.5 \%$ & $44.6 \%$ \\
\hline United States-\% & $53.5 \%$ & $55.4 \%$ \\
\hline
\end{tabular}

International registered firms and those currently performing audit functions represent $46.5 \%$ and $44.6 \%$, respectively, of the total number of firms. The five largest countries of origin for international firms registered and performing audit functions currently are Canada (26), China (15), India (15), Hong Kong (12), and United Kingdom (12), totaling 80 of the 287 performing audits or $28 \%$ of the total. From the information on settled disciplinary actions and registered firms, it is evident that the current settled international firm enforcement of $44.4 \%$ is close to the percentage of international registered firms currently auditing, 44.6\% (PCAOB, 2017).

\section{CONCLUSIONS}

Information on the whistleblower and anti-retaliation provisions of both Sarbanes-Oxley and the Dodd-Frank Act show that Congress realizes the need for strong federal programs. The first of its kind international data shows that economic crime is an ever-present and global problem and that many foreign whistleblowers will report even in the face of retaliation, but many do stay silent because they fear retaliation. Whistleblower tips and anti-retaliation measures, strengthened under Dodd-Frank, are proving largely to be successful, but there are legal challenges to be decided that could impact the protection to those who only choose to report internally, and more concerning is the lack of anti-retaliation protection for foreign whistleblowers. This paper provided information showing the number of tips by internationals is generally consistent with the number of international registrants. Awards to foreign nationals may indicate they are willing to come forward regardless of the lack of protection. Registration numbers of international firms with the PCAOB and settled disciplinary proceedings shows increased international enforcement at least in the area of international accounting firms. 


\section{REFERENCES}

Carozza, D. (2009). Chasing Madoff: An interview with Harry Markopolos, CFE, CFA. Fraud Magazine. Retrieved from http://www.fraud-magazine.com/article.aspx?id=313

Christian, M., Rosenfeld, R., Lakatos, A., Hanchet, M., \& Bisanz, M. (2014). Presumption against extraterritoriality in Morrison v. National Australia Bank extended to private party whistleblower retaliation cases. MayerBrown Legal Update. Retrieved from https://www.mayerbrown.com/Presumption-Against-Extraterritoriality-in-emMorrison-vNational-Australia-Bank

Dechert, LLC. (2017). Supreme Court to clarify definition of "whistleblower" under the Dodd-Frank Act. Retrieved from http:/www.jdsupra.com/legalnews/supreme-court-to-clarify-definition-of-83896/

Elgadeh, M. (2011). Morrison v. National Austria Bank: Life after Dodd-Frank. Fordham Journal of Corporate and Financial Law, XVI, 573-600.

Ethics \& Compliance Initiative (2016). Global Business Ethics Survey. Retrieved from https://www.ethics.org/ecihome/research/gbes

Fredin, A. (2012, April). The unexpected cost of staying silent. Strategic Finance, 53-59.

Gilpin, D. (2017). Hiding behind the veil of ambiguity: Why courts should apply the plain meaning of the Dodd-Frank whistleblower provisions. St. John's Law Review, 90, 851-882.

Hannen, B. (2017). Investigating the shrinking number of SEC registrants. Retrieved from $\mathrm{http} / /$ www.auditanalytics.com/blog/investigating-the-shrinking-number-of-sec-registrants/

Miralem, I. (2011). The SEC's whistleblower program and its effect on internal compliance programs. Case Western Reserve Law Review, 62(1), 333-350.

Office of the Whistleblower. Securities and Exchange Commission (2011-2016). Annual Report on the Dodd-Frank Whistleblower Program. Retrieved from https://www.sec.gov

Public Company Accounting and Oversight Board (2017). Statistics on registered firms and enforcement actions. Retrieved from https://pcaobus.org//

PricewaterhouseCoopers (2016). Global Economic Crime Survey. Retrieved from https://www.pwc.com/gx/en/services/advisory/forensics/economic-crime-survey.html

Sipe, S. R, Metrejean, C. T., \& Pearson, T.A. (2014). The SEC, the courts and whistleblowers: An examination into the strengths of the anti-retaliation provisions of the Dodd-Frank Act as defined by recent Federal court decisions. Journal of Legal Studies in Business, 19, 1-19.

Shimabukuro, J.O., Whitaker, L.P., \& Roberts, E. E. (2013). Survey of federal whistleblower and antiretaliation laws. Congressional Research Service, R43045.

Uliassi, T. (2011). Addressing the unintended consequences of an enhanced SEC whistleblower bounty program. Administrative Law Review, 6(2), 351-379. 